\section{'Lakota' Winter Squash, A Cultivar Derived from Native American Sources in Nebraska}

\author{
D.P. Coyne, J.M. Reiser, and Lisa Sutton \\ Department of Horticulture, University of Nebraska, Lincoln, NE 68583
}

\section{Alice Graham \\ 1802 Dawes Street, Ashland, NE 68003}

Additional index words. Cucurbita maxima, landrace, fruit color variegation, fruit color instability, breeding

'Lakota' is a novel, smooth- and thinskinned, small-fruited, early maturing, ovoidshaped winter squash [Cucurbita maxima (Duch.)] (Fig.1). Plants produce fruit exhibiting various degrees of green and orange variegated patterns, along with some solid green and orange fruit. 'Lakota' was released because of its novel decorative value and good baking quality. A similar winter squash is not available commercially.

\section{Origin}

Seeds of the winter squash population from which 'Lakota' was selected were donated to the Univ. of Nebraska, Lincoln, by A.G., who originally received the seed from the late Martha Newman, Alliance, Neb. By examining the Quarter Master Reports (1820), A.G. was able to determine that the original squash landrace was grown by Native Americans living along the Missouri Valley and that this squash also was grown in gardens by troops stationed at Fort Atkinson in northeastern Nebraska; subsequently, troops stationed at the later-developed Fort Robinson (1870 to 1875) in northwestern Nebraska obtained seeds of this squash landrace from Fort Atkinson, grew it in their gardens, and stored it in cellars for use during the winter (U.S. Army Quarter Master Reports for Fort Robinson, 1870). Newman, living on a homestead in northwestern Nebraska, apparently received seeds of the squash landrace from her brother, Alfred Iossi, who was a civilian employee at Fort Robinson (the late Martha Newman, personal communication). Eventually, the Newman family moved to Alliance in western Nebraska, brought the seeds with them, and raised the squash each

Received for publication 8 Aug. 1995. Accepted for publication 30 Mar. 1995. Published as paper no. 10819, Journal Series, Nebraska Agricultural Research Division. Research was conducted under former Project 20-14. We appreciate grants from Hollar Seed, Rocky Ford, Colo., in partial support of the breeding program and the technical assistance of Katie Rochford, Carol Lyman, and Steve Magnuson in Lincoln, Neb. The cost of publishing this paper was defrayed in part by the payment of page charges. Under postal regulations, this paper therefore must be hereby marked advertisement solely to indicate this fact. year. Although this squash has excellent baking quality (personal observation), it was never introduced into commerce.

Fruit of the original landrace were described as being elongated ( 75 to $85 \mathrm{~cm}$ long, 20 to $25 \mathrm{~cm}$ in diameter) and cylindrical, with dark green and orange variegated skin patterns. Although the fruit shape is nearly similar, it is smaller than the C. maxima banana type (Casttetter and Erwin, 1927). The Winnebago Indians of eastern Nebraska also grew a $C$. maxima landrace with similarly shaped fruit, but the fruit were smaller, warty, and dark green. 'Winnebago', which was derived from this landrace, was introduced by Oscar H. Will Co. in the 1920s (Casttetter and Erwin, 1927; Tapley et al., 1937).

In Lincoln, only one of 200 plants grown from the seed donated by A.G. produced fruit resembling the original description (elongated and cylindrical with mottled orange and green harvest $(12$-inch ruler $=30.5 \mathrm{~cm})$. skin color pattern). The segregation pattern of fruit shape suggested that the original landrace was outcrossed to hubbard squash because many fruit were ovoid and some were ovoid with pointed ends, similar to those of hubbard squash. Casttetter and Erwin (1927) described hubbard squash as "nearly spherical, tapering into a neck at the stem end and to [a] curved, pointed projection at the blossom end." According to Newman, her population also deviated from the original type, suggesting that the original landrace was outcrossed in her garden in Alliance during the intervening years (personal communication). The variation in fruit shape, color, and size in the population grown at Lincoln provided an opportunity to select for a novel, decorative, small, ovoid squash of good baking quality.

The inbred line NE IS-88-12 was developed by six generations of selfing a plant derived from the outcrossed Indian squash population from western Nebraska previously noted. The name 'Lakota' (a dialect of the Sioux) was assigned to this line because the outcrossed population of the original landrace came from western Nebraska, an ancestral home of the Sioux. The Sioux nation was not involved in its development.

Selected inbred lines $\left(\mathrm{S}_{6}\right)$, with solid orange or solid green fruit, continued to breed true for these colors. The inbred lines that produced mainly fruit with mottled orange and green color patterns (variegated fruit) also produced varying proportions of plants with solid orange and green fruit. 'Lakota' was the most uniform for the orange and green color patterns of these inbred variegated lines. We hypothesized that two major dominant genes determined the variegated fruit-color pattern (Coyne and Rochford, 1987). The dominant

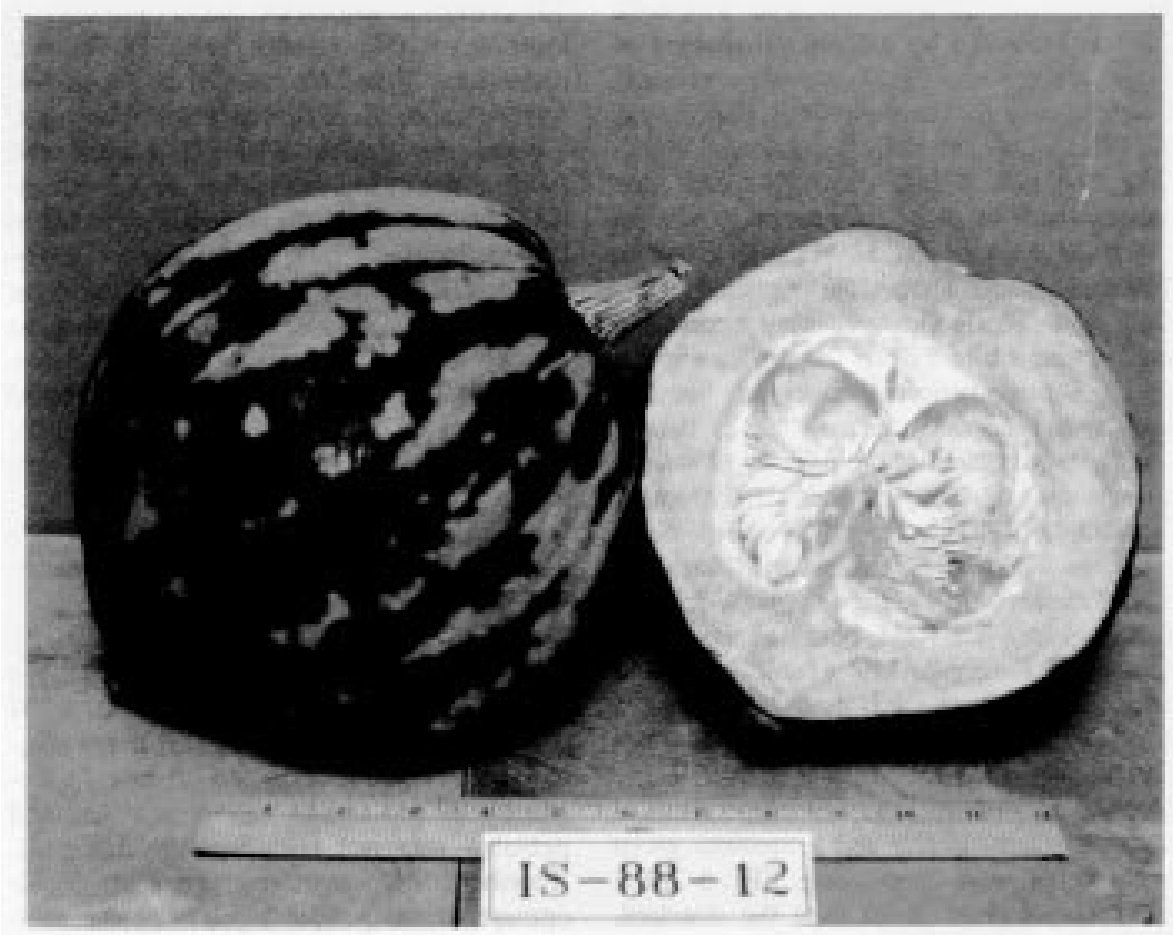

Fig. 1. Mature variegated (orange and green) fruit of the 'Lakota' squash [Cucurbita maxima (Duch.)] at 
gene $O$ determines orange pigmentation, and the dominant gene $M$ inhibits the expression of $O$ in some fruit areas during fruit development, causing the variegated fruit pattern.

\section{Description}

Fruit color of 'Lakota' was evaluated in six trials (1984 to 1991) conducted at Lincoln (Table 1); variation existed in all trials. Most fruit exhibited variegated green and orange patterns, but some fruit were solid green. In one trial, some fruit also had solid orange skin. The fruit color instability of 'Lakota' also has been observed by L. Hollar (Hollar Seed, Rocky Ford, Colo.) in California and Colorado and by R. Johnson (Johnny's Selected Seeds, Albion, Maine) in Maine (personal communications). Some fruit that had solid green or orange skin grew at these locations. We attribute the variation in fruit color patterns to a difference in developmental pattern of pigmentation under distinct environments. 'Lakota' is an inbred line and breeds true for fruit shape, plant habit, and time of maturity. The mesocarp flesh of 'Lakota' is deep yellow, regardless of growing environment.

In Lincoln, 'Lakota' yield was compared in four trials (1988 to 1991) to two small hubbards ['Improved Green' (Rogers Seed Co.) and an experimental sister line to 'Lakota', Indian Squash-Green] (Table 2). Indian Squash-Green is a true-breeding, green-fruited, small, near-hubbard type also selected from the original Indian squash donated by A.G. 'Lakota' plants yielded significantly heavier fruit than those of 'Improved Green' in two of the four trials. However, Indian Squash-Green outyielded 'Lakota' in one trial. The fruit weight of 'Lakota' (2.1 to $3.0 \mathrm{~kg}$ ) was similar to that of the other entries. The maximum diameter of the cut fruit is $\approx 17.5 \mathrm{~cm}$. 'Lakota' fruit had little or no solar injury in Nebraska, but solar injury and subsequent fruit rot were severe on the solid-green-fruited lines (data not presented).

Vine spread of 'Lakota' is $\approx 3$ to $4 \mathrm{~m}$. The number of days to fruit maturity at Lincoln is $\approx 98$ to 105 days. 'Lakota' is susceptible to squash vine borer; however, more 'Lakota' plants $(88 \%$ to $92 \%)$ survived vine borer injury than those of the other entries (48\% to $74 \%$ ) in 1990. Survival was similar for all entries in 1992. Although 'Lakota' is thin- skinned, it stored well at 15 to $20 \mathrm{C}$ when the rinds were not punctured by insects.

\section{Availability}

An exclusive release of this cultivar was made in 1992 to Hollar Seeds, P.O. Box 106, Rocky Ford, CO 81007.

\section{Literature Cited}

Casttetter, E.F. and A.T. Erwin. 1927. A systematic study of the squashes and pumpkins. Iowa Agr. Expt. Sta. Bul. 244:107-135.

Table 1. Percentage of fruit in fruit color classes of winter squash cultivars/lines.

\begin{tabular}{|c|c|c|c|c|c|c|c|}
\hline \multirow[b]{2}{*}{ Cultivar/line } & \multirow[b]{2}{*}{ Years $^{y}$} & \multicolumn{6}{|c|}{ Fruit color classes $(\%)^{2}$} \\
\hline & & $\begin{array}{l}\text { Solid } \\
\text { green }\end{array}$ & $\begin{array}{c}\text { Mostly } \\
\text { green, some } \\
\text { orange }\end{array}$ & $\begin{array}{c}\text { Equal } \\
\text { green and } \\
\text { orange }\end{array}$ & $\begin{array}{c}\text { Mostly } \\
\text { orange, } \\
\text { some green }\end{array}$ & $\begin{array}{c}\text { Solid } \\
\text { orange }\end{array}$ & $\begin{array}{l}\text { Total no } \\
\text { fruit in } \\
\text { samples }\end{array}$ \\
\hline \multirow[t]{6}{*}{ Lakota } & 1984 & 28 & 32 & 28 & 12 & 0 & 25 \\
\hline & 1985 & 0 & 14 & 7 & 58 & 22 & 59 \\
\hline & $1988(\text { Trial 1 })^{\mathrm{x}}$ & 0 & 48 & 43 & 9 & 0 & 23 \\
\hline & 1988 (Trial 2) & 0 & 26 & 26 & 48 & 0 & 27 \\
\hline & 1990 & 12 & 84 & 4 & 2 & 0 & 50 \\
\hline & 1991 & 28 & 65 & 4 & 2 & 0 & 49 \\
\hline \multirow{2}{*}{$\begin{array}{l}\text { IS-Green }^{\mathrm{w}} \\
\text { Improved Green }^{\mathrm{v}}\end{array}$} & $1984,1988,1991$ & 100 & 0 & 0 & 0 & 0 & 105 \\
\hline & 1984, 1985, 1988, & 100 & 0 & 0 & 0 & 0 & 201 \\
\hline IS-Orange $^{w}$ & 1984,1988 & 0 & 0 & 0 & 8 & 92 & $\begin{array}{r}201 \\
36\end{array}$ \\
\hline
\end{tabular}

${ }^{2}$ The percentage of 'Lakota' fruit is presented each year in classes because of the large variation within and between years.

${ }^{y}$ Data were summarized over years because no or only slight variation existed among the entries. ${ }^{x}$ Two trials in separate fields were conducted.

"wS = Indian squash (IS-Green and IS-Orange are solid-colored-fruited sister lines of 'Lakota'). "Source: Roger Seed Co., Gilroy, Calif.

Table 2. Marketable yield and fruit weight of winter squash cultivars/lines grown in Lincoln, Neb. ${ }^{2}$

\begin{tabular}{|c|c|c|c|c|c|c|c|c|}
\hline \multirow[b]{4}{*}{ Cultivar/line } & \multicolumn{8}{|c|}{ Year of trial } \\
\hline & \multicolumn{4}{|c|}{$1988^{y}$} & & & & \\
\hline & \multicolumn{2}{|c|}{ Trial 1} & \multicolumn{2}{|c|}{ Trial 2} & \multicolumn{2}{|c|}{1990} & \multicolumn{2}{|c|}{1991} \\
\hline & 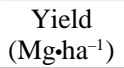 & $\begin{array}{l}\text { Fruit wt } \\
(\mathrm{kg})\end{array}$ & 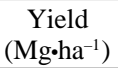 & $\begin{array}{l}\text { Fruit wt } \\
(\mathrm{kg})\end{array}$ & 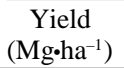 & $\begin{array}{l}\text { Fruit wt } \\
(\mathrm{kg})\end{array}$ & 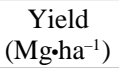 & $\begin{array}{c}\text { Fruit wt } \\
(\mathrm{kg})\end{array}$ \\
\hline Lakota & 11.7 & 3.0 & 17.4 & 3.0 & 14.3 & 2.2 & 13.7 & 2.1 \\
\hline IS-Green ${ }^{x}$ & 12.2 & 3.3 & 22.1 & 4.0 & --- & --- & 12.6 & 2.2 \\
\hline Improved & & & & & & & & \\
\hline Green $^{w}$ & 6.3 & 3.2 & 15.0 & 3.6 & 5.7 & 2.3 & 13.6 & 2.6 \\
\hline $\mathrm{LSD}_{0.05}$ & 2.1 & $\mathrm{NS}^{\mathrm{v}}$ & 4.1 & NS & 3.0 & NS & NS & NS \\
\hline
\end{tabular}

${ }^{2} \mathrm{~A}$ randomized complete-block design with three to five replications was used in all tests. Single-row plots were spaced $2.4 \mathrm{~m}$ apart with five plants per entry transplanted $1.2 \mathrm{~m}$ apart within rows.

yTwo trials in separate fields were conducted.

'IS = Indian Squash (IS-Green is a solid-colored-fruited sister line of 'Lakota').

${ }^{w}$ Source: Rogers Seed Co., Gilroy, Calif.

${ }^{{ }_{N} \mathrm{~N}}=$ nonsignificant. 